\title{
Habitat and population estimates of some threatened lowland forest bird species in Tambopata, south-east Peru
}

\author{
HUW LLOYD
}

\section{Summary}

Surveys of threatened lowland forest bird species and forest habitats were conducted during a 21-month census of lowland bird communities in Tambopata, Department of Madre de Dios, south-east Peru. A combination of distance sampling census methods and direct counts was used for the census in five sites located along the Rio Madre de Dios and Rio Tambopata. All five sites consisted of different forest types with significantly different habitat components. Three of these sites were classified as primary forest habitats whilst the remaining two were classified as disturbed forests. Population densities were calculated for eight of the threatened species recorded during the census. Density estimates of non-bamboo specialists were higher in primary forest habitats than in disturbed forest habitats. Density estimates of most bamboo specialists were higher in primary Old Floodplain forest with extensive bamboo understorey than in primary Middle/Upper Floodplain forest with smaller, patchy areas of bamboo understorey. Calculation of regional population estimates based on the amount of forest cover from satellite photographs shows that only two of the threatened bird species have substantial populations currently protected by the Parque Nacional Bahuaja-Sonene and Reservada Nacional de Tambopata. Selective logging operations that reduce overall tree biomass and remove a large proportion of palm tree species from primary forest habitats will have an adverse affect on local populations of four of the threatened bird species in the region.

\section{Introduction}

Estimation of population size and quantitative descriptions of habitat can provide a strong foundation for the conservation of lowland forest bird species (Kratter 1995b). The value of such an approach may come from predicting distribution and numbers in unsurveyed areas, providing an understanding of the nature of the relationship between a bird species and its habitat, and also predicting possible consequences of future changes of land use (Bibby et al. 1998). Estimation of population size for globally threatened bird species has a more special importance since the current IUCN criteria for ranking the degree of threat to any species are highly quantitative (Collar et al. 1994), but these criteria are practical only to the extent that data can be brought to bear on them. Traditionally, conservation action in Amazonian lowland forests has relied largely on targeting and conserving large tracts of undisturbed areas in the hope that these contain a major proportion of the important habitats and species in the area (Foster et al. 1994, Kratter 1995b). 
Following the creation of the 1,480,000 ha Zona Reservada de TambopataCandamo (ZRTC) in south-eastern Peru in 1990, 325,000 ha of the lowland forest and pampas grassland habitat were officially established as the Parque Nacional Bahuaja-Sonene (PNBS) in 1996. The remainder was still incorporated within the ZRTC. Following widespread local and international consultation, the Peruvian government announced the doubling in size of the PNBS and the creation of the Reservada Nacional de Tambopata (RNT) in September 2000. The announcement followed the final withdrawal of oil exploration in August that year. As a result, PNBS has increased in size from 325,000 ha to $1,091,416$ ha. Most of this extension lies in the department of Puno and covers the Candamo and Tavara foothills. An area of 262,315 ha has been designated as a buffer zone to the RNT and includes the four native communities along the Rio Tambopata and others along the Cusco-Puerto Maldonado road. The RNT (254,358 ha) covers much of the remaining area of the former ZRTC.

The floodplain forests of south-east Peru represent the most threatened forest types of the region (Phillips et al. 1994). Floodplain forests are less extensive than upland terra firme forests, and mature floodplain forests in western Amazonia are being deforested faster than other lowland forest types as human settlement and agriculture spread outward from riverbanks (Phillips et al. 1994). Floodplain forests not only have extremely diverse avifauna and flora, but many endemic bird species in south-western Amazonia appear to be restricted to particular successional stages found only in these forests (Foster et al. 1994, Phillips et al. 1994, Kratter 1995b, Robinson and Terborgh 1997). All other endemics are bamboo specialists (Kratter 1995b, 1997).

A total of 16 species are identified by Parker et al. (1996) in Stotz et al. (1996). as "vulnerable", with habitat destruction being the primary threat to these species: Pale-winged Trumpeter Psophia leucoptera, Crested Eagle Morphnus guianensis, Harpy Eagle Harpia harpyja, Red-throated Caracara Daptrius americanus, Orange-breasted Falcon Falco deiroleucus, Blue and Yellow Macaw Ara ararauna, Scarlet Macaw Ara macao, Red and Green Macaw Ara chloroptera, Amazonian Parrotlet Nannopsittaca dachilleae, Rufous-headed Woodpecker Celeus spectabilis, Bar-bellied Woodcreeper Hylexetastes stresemanni, Manu Antbird Cecromacra manu, Rufous-fronted Antthrush Formicarius rufifrons, Whitecheeked Tody-Tyrant Poecilotriccus albifacies, Black-faced Cotinga Conioptilon mcilhennyi and Slate-coloured Seedeater Sporophila schistacea. Four of these species were identified by BirdLife International (2000) as Near Threatened (M. guianensis, H. harpyja, N. dachilleae and F. rufifrons), as was an additional species, Peruvian Recurvebill Simoxenops ucayalae that was not regarded as threatened by Parker et al. (1996). Two additional species, Scarlet-hooded Barbet Eubucco tucinkae and Purple-throated Cotinga Porhyrolaema porhyrolaema, that were formerly considered Least Concern or Data Deficient are now no longer considered to be at risk whilst two further species, Long-crested Pygmy Tyrant Lophotriccus eulophotes, identified as vulnerable by Parker et al. (1996) and Elusive Antpitta Grallaria eludens, identified as Near Threatened by BirdLife International (2000), are not reported from the Tambopata area.

In this paper I present data from a 21-month survey of lowland forest bird populations and forest habitats at five locations in the Tambopata region from January 1997 to September 1998. Firstly I aimed to provide detailed quantitative 
descriptions of the forest habitats at each site situated along the Rio Madre de Dios and Rio Tambopata and assess any differences between habitats. Secondly I aimed to examine and compare density estimates of each threatened bird species in each habitat. Thirdly I aimed to calculate population estimates for the most threatened forest bird species in the Tambopata region and to estimate the size of the populations now afforded protection under the newly created RNT and PNBS.

\section{Methods}

\section{Study sites}

Forest habitats were classified using the system derived by Phillips (1993), and tested by Nicholson and Edwards (1994). EcoAmazonia Lodge (EA) is situated on the north bank of the lower region of the Rio Madre de Dios $\left(12^{\circ} 31^{\prime} S\right.$, $68^{\circ} 55^{\prime} \mathrm{W}$; elevation $205 \mathrm{~m}$ ) outside the Parque Nacional Bahuaja-Sonene (Figure 1). The primary habitat at EA is Seasonally Flooded Swamp forest. The Cusco Amazonico Reserve (CA) is also situated on the north bank of the Rio Madre de Dios $\left(12^{\circ} 32^{\prime} \mathrm{S}, 69^{\circ} 3^{\prime} \mathrm{W}\right.$; elevation $210 \mathrm{~m}$ ). The predominant forest type at CA is a mosaic of Old Floodplain and Seasonally Flooded Swamp forest. The Explorers Inn Reserve (EI) is a 5,500 ha reserve situated on the Rio Tambopata around its confluence with the Rio La Torre $\left(12^{\circ} 50^{\prime} \mathrm{S}, 69^{\circ} 17^{\prime} \mathrm{W}\right)$ about $40 \mathrm{~km}$ south-west of Puerto Maldonado (Nicholson and Edwards 1994). Phillips (1993) and Nicholson and Edwards (1994) have previously described the vegetation types of the reserve. Surveys were conducted in Terra Firme Sandy Clay Forest that occupies large areas of higher ground in the reserve. The Sachavacayoc Centre (SA) is situated on the south bank of the Rio Tambopata $\left(12^{\circ} 51^{\prime} \mathrm{S}\right.$, $69^{\circ} 21^{\prime} \mathrm{W}$; elevation $217 \mathrm{~m}$ ) within the RNT. The dominant habitat is Old Floodplain forest with extensive areas of understorey Guadua bamboo. The Tambopata Research Centre (TRC) is situated on the north bank of the Rio Tambopata $\left(13^{\circ} 8^{\prime} \mathrm{S}, 69^{\circ} 37^{\prime} \mathrm{W}\right.$; elevation $230 \mathrm{~m}$ ) in the upper region of the river, some $75 \mathrm{~km}$ south-south-west of Puerto Maldonado, in the RNT. The main area of forest in proximity to the Centre is a mosaic of Middle/Upper Floodplain forest.

\section{Bird surveys}

I used two census methods for the bird surveys. The Variable Circular Plot (VCP) method (Reynolds et al. 1980) adapted by Jones et al. (1995) was used as the principal census method. A total of 39 census stations were established along six transects at EA, 24 stations along six transects at CA, 39 stations along eight transects at EI, 39 stations along nine transects at SA, and finally 26 stations along three transects at TRC. Census stations were located $200 \mathrm{~m}$ apart on each transect. Transects were established either perpendicular across existing trails, along existing trails, or in areas where there were no trail systems. The number of census stations and the length of each transect at each site were dependent on the amount of available habitat at each site.

Between January and September of 1997 and 1998, VCP surveys began at o5h3o and were concluded by o8h30, after which time vocal activity decreased 


\section{Tambopata Region of south-east Peru}

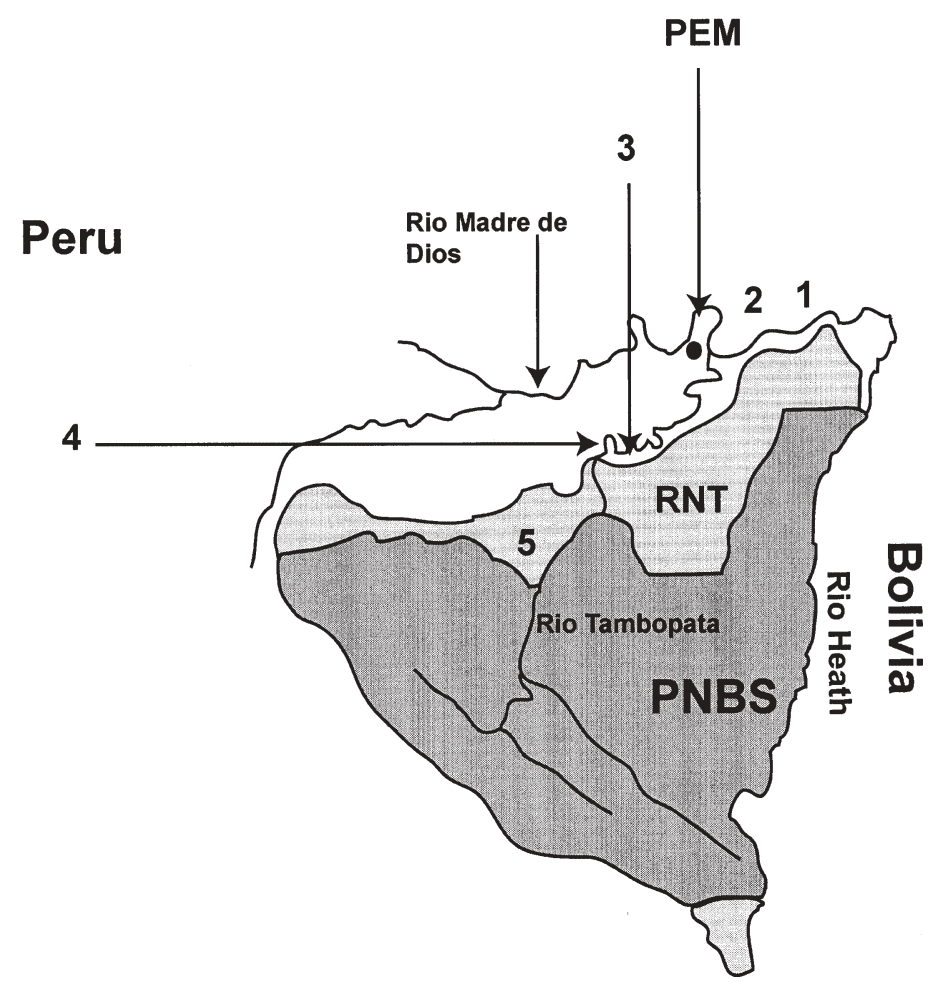

Figure 1. Tambopata region of south-east Peru. PNBS, Parque Nacional Bahuaja-Sonene; RNT, Reservada Nacional de Tambopata; 1, EcoAmazonia; 2, Cusco Amazonica Reserve; 3, Explorers Inn Reserve; 4, Sachavacayoc Centre; 5, Tambopata Research Centre; PEM, Puerto Maldonado.

significantly. During the months of September to December, first light occurred earlier in the morning. Thus VCP surveys had to begin at $04 \mathrm{~h} 45$ in order to adequately census birds that sang during the predawn chorus (Terborgh et al. 1990). Two observers spent $10 \mathrm{~min}$ at each census station recording all bird contacts. These contacts were assigned to one of three categories: seen, heard or seen, and heard. Observers noted the time of the contact, species, and the number of individuals. Observers then estimated horizontal distance from the centre of the census station to each individual contact. Finally each bird contact was assigned to one of five height categories: $1=$ ground level $(<1 \mathrm{~m})$; $2=$ understorey $(1-5 \mathrm{~m}) ; 3=$ mid-canopy $(5-15 \mathrm{~m}) ; 4=$ canopy; $5=$ flying above the canopy. For parrot species that habitually occur in monotypic flocks, distance estimates were made from the census station to the geometric centre of the flock. For heard-only contacts, mean group size for that species was substituted for the missing group size values. These were calculated from a total of 997 separate observations of the 18 local species from all five sites during the 21-month period. 
A total of six repeat surveys (each survey lasting 18 days) was made at EA while five repeat surveys were made at CA and SA and four at both EI and TRC. The number of surveys at each site was determined by the permission of the lodge-owners. Two repeats of each transect were made per visit to each site. The direction of the surveys along each transect was rotated to counter the bias of bird activity and the time of day. Distance data were then analysed using the program DISTANCE v. $3 \cdot 5$ (Thomas et al. 1998).

A Variable-Distance Line Transect method (VDLT; Buckland et al. 1993) was also used to census P. leucoptera at three of the five sites during September 1997 to September 1998 as part of a separate census of nocturnal bird species. Each census was conducted between 18 hoo and 1oh30. At all three sites transect length varied from 1,115 $\mathrm{m}$ to 3,700 $\mathrm{m}$. Two transects were situated at both EA and TRC, with three transects situated at SA. Each transect was marked at $25 \mathrm{~m}$ intervals and was located either along existing trails or away from the trail system. Transects were walked at a slow but steady pace. The observer recorded the time of each contact, the species, number of individuals, the distance to the nearest transect marker, and an estimate of distance from the estimated geometric centre of each group perpendicular to each transect. One to three repeats of each transect were made per visit and distance data were analysed using the program DISTANCE v.3.5 (Thomas et al. 1998).

Diurnal raptor species encountered during VCP surveys are referred to as either present or absent, since diurnal raptor species are difficult to census accurately due to the lack of standardized methodology, low population densities, large territory sizes and inconspicuous behaviour (Thiollay 1989, Robinson 1994). Direct counts of territorial pairs were conducted on two species of bamboo specialists, C. spectabilis and C. manu, at SA during May and June 1998 following no standardized methodology. Population densities and estimates for these species are expressed as number of pairs. I recognize the problems of including data from this unstandardized method here. However, I emphasize the importance of their inclusion here since both these species are considered globally threatened by Parker et al. (1996), they show high levels of habitat specificity (Kratter 1995b) and represent an important component of the bamboo bird community.

\section{Habitat sampling}

Features of the habitat were also recorded at each VCP census station between September 1997 and September 1998. Percentage vegetation cover at each census station was estimated using a sighting tube (Bibby et al. 2000). Vegetation cover was estimated at four different height categories: ground level $(<\mathrm{I})$, understorey level ( $1-5 \mathrm{~m})$, mid-canopy level (5-15 m) and canopy level. At each census station within a $30 \mathrm{~m}$ radius, the 10 nearest trees with a diameter at breast height $(\mathrm{DBH})$ of $>0.2 \mathrm{~m}$ were selected and labelled with aluminium tags. For each tree the following variables were recorded: estimate of height, girth, distance to the centre of the census station, dead or alive, presence or absence of viney tangles and lianas, and whether or not the tree was a species of palm.

An indication of the past history of each site was provided by recording tree "architecture" using a method developed by Jones et al. (1995) adapted from 
Torquebiau (1986). Each of the 10 trees was allocated to one of the following groups: crown of the tree branches above half its height (trees which have developed under the closed canopy of primary forest tend to have the first major branching of the crown well above half their height); branching below half their height (trees which have developed in more open canopies usually have the major branching of the crown below half their height); and presence or absence of scars (when a tree grows under an open, broken forest cover e.g. around tree falls or in secondary forest, there may be a secondary reaction to the closure of the forest canopy, and this "regeneration" sometimes takes the form of a shedding of the lower major branches, leaving a scar on the main trunk).

The habitat data were manipulated in various ways before analysis. Tree density was calculated as the number of large woody trees per square metre per census station. Estimate of total area of forest habitat was taken from Kratter (1995b) calculated from a Landsat satellite image of the region (Earth Observation Satellite Company 1991, Foster et al. 1994, Kratter 1995b). The satellite image corresponded to the same area in this study and covered approximately $12^{\circ} 15^{\prime}-13^{\circ} 32^{\prime} \mathrm{S}$ and $68^{\circ} 10^{\prime}-69^{\circ} 40^{\prime} \mathrm{W}$ of lowland south-east Peru (departments of Madre de Dios and Puno) and northern Bolivia (Kratter 1995b).

\section{Results}

\section{Habitat analysis}

A total of 1,386 trees were marked and monitored. On average, the Seasonally Flooded Swamp forest at EA had the largest and tallest trees, a greater percentage of trees with viney growth and woody lianas, and also a highest number of trees branching below half their height and showing signs of regeneration (Table 1). The highest number of tree fatalities was also recorded at this site, with six trees felled over the 12-month period leaving a total of 14 dead trees of the 289 recorded. The Middle/Upper Floodplain forest at TRC on average had the greatest estimated percentage canopy vegetation cover and the least dense estimated ground and understorey vegetation cover. Old Floodplain forest at SA had the highest number of palm trees but the least number of trees branching below half their height and showing signs of regeneration. The shortest trees with the lowest recorded $\mathrm{DBH}$ were recorded in the Terra Firme Sandy Clay

Table 1. Mean values of habitat variables recorded at each census station, at each of the five survey sites. Tree density is expressed as number of large woody trees per hectare.

\begin{tabular}{|c|c|c|c|c|c|c|c|c|c|c|}
\hline Location & $\begin{array}{l}\text { Total no.* } \\
\text { of trees }\end{array}$ & $\begin{array}{l}\text { Tree } \\
\text { density }^{*}\end{array}$ & $\begin{array}{l}\text { No. of } \\
\text { palm } \\
\text { trees* }\end{array}$ & $\begin{array}{l}\% \text { trees } \\
\text { with } \\
\text { vines* }\end{array}$ & $\begin{array}{l}\mathrm{DBH} \\
(\mathrm{m})^{*}\end{array}$ & $\begin{array}{l}\text { Height } \\
(\mathrm{m})^{*}\end{array}$ & $\begin{array}{l}\text { Ground } \\
\text { cover } \\
(\%)^{*}\end{array}$ & $\begin{array}{l}\text { Low } \\
\text { cover } \\
(\%)^{*}\end{array}$ & $\begin{array}{l}\text { Mid- } \\
\text { canopy } \\
\text { cover } \\
(\%)^{*}\end{array}$ & $\begin{array}{l}\text { Canopy } \\
\text { cover } \\
(\%)^{*}\end{array}$ \\
\hline EA & 289 & 119 & 44 & 51.9 & 0.56 & 23.4 & 20.3 & 37.2 & 55.5 & $57 \cdot 5$ \\
\hline CA & 240 & 160 & 52 & 41.7 & 0.48 & 19.1 & 29.8 & 39.2 & 48.1 & 67.1 \\
\hline EI & 300 & 177 & 32 & 43.0 & 0.40 & 18.5 & 19.5 & 41.5 & 62.5 & 56.0 \\
\hline SA & 297 & 128 & 85 & 35.4 & 0.55 & 19.4 & 35.0 & 35.0 & 58.2 & 58.8 \\
\hline TRC & 260 & 177 & 83 & 28.8 & 0.43 & 20.6 & 17.1 & 29.4 & $41 \cdot 3$ & 68.6 \\
\hline
\end{tabular}

*denotes significant difference between each forest type (one-way ANOVA, $P<0.05$ ). 
forest at EI, which on average also had the lowest average tree density, an open estimated canopy vegetation cover and the second highest number of trees showing signs of regeneration. None of the tagged trees at this site died during the 12 months of observation. A one-way ANOVA test showed that all habitat variables differed significantly between all five sites (Table 1).

Principal Component Analysis (PCA) was used to compress the set of variables into a smaller number of axes of habitat variability (Norusis 1993). The result of the PCA was the reduction of the data set to five components explaining $65.2 \%$ of the variability. PCA1 corresponded to primary forest architecture (high positive and negative scores for number of trees branching above or below half their height), explaining $16.1 \%$ of the variation. PCA2 corresponded to tree biomass (high positive scores for both mean $\mathrm{DBH}$ and basal area), explaining $14.5 \%$ of the variation. PCA 3 corresponded to density of palm trees, vines and lianas (high positive score for palms and high negative score for woody vines and lianas), explaining $13.3 \%$ of the variation. PCA4 corresponded to understorey vegetation cover (high negative score), explaining $11.5 \%$ of the variation. Finally, PCA5 corresponded to the density of canopy vegetation (high positive score), explaining $9.8 \%$ of the variation.

Mean PCA scores for each of the variables give an indication of the status of each forest habitat (Table 2). EA had a high negative mean score for forest

Table 2. Mean PCA loadings for each of the PCA habitat variables for all five sites. One-way ANOVA test was used to test for significant differences for each variable between each site.

\begin{tabular}{|c|c|c|c|c|}
\hline Variable & $\begin{array}{l}\text { Location and no. of } \\
\text { census stations }\end{array}$ & Mean & $\mathrm{SD}$ & One-way ANOVA \\
\hline Forest architecture & EA 30 & -0.514 & 1.320 & $F=4.857$ \\
\hline \multirow[t]{4}{*}{ PCA1 } & CA 24 & 0.280 & 0.721 & d.f. $=139$ \\
\hline & EI 30 & -0.197 & 0.157 & $P<0.05$ \\
\hline & $\mathrm{SA}_{30}$ & 0.466 & 0.178 & \\
\hline & TRC 26 & 0.002 & 0.123 & \\
\hline Tree biomass & $\mathrm{EA}_{30}$ & 0.372 & 1.197 & $F=5.988$ \\
\hline \multirow[t]{4}{*}{$\mathrm{PCA} 2$} & CA 24 & 0.002 & 0.644 & d.f. $=139$ \\
\hline & $\mathrm{EI} 30$ & -0.548 & 0.473 & $P<0.001$ \\
\hline & SA 30 & 0.420 & 1.358 & \\
\hline & TRC 26 & -0.308 & 0.530 & \\
\hline $\begin{array}{l}\text { No. of palm trees/vines/ } \\
\text { lianas }\end{array}$ & $\mathrm{EA}_{30}$ & -0.517 & 0.733 & $F=11.551$ \\
\hline \multirow[t]{4}{*}{$\mathrm{PCA}_{3}$} & CA 24 & -0.002 & 0.947 & d.f. $=139$ \\
\hline & $\mathrm{EI} 30$ & -0.443 & 0.766 & $P<0.001$ \\
\hline & SA 30 & 0.231 & 0.953 & \\
\hline & TRC 26 & 0.875 & 0.980 & \\
\hline Tree height & $\mathrm{EA}_{30}$ & 0.639 & 1.485 & $F=5.267$ \\
\hline \multirow[t]{4}{*}{$\mathrm{PCA}_{4}$} & CA 24 & -0.229 & 0.734 & d.f. $=139$ \\
\hline & EI 30 & -0.101 & 0.843 & $P<0.05$ \\
\hline & $\mathrm{SA}_{30}$ & -0.402 & 0.725 & \\
\hline & TRC 26 & 0.002 & 0.567 & \\
\hline \multirow{5}{*}{$\begin{array}{l}\text { Estimated \% canopy cover } \\
\text { PCA } 5\end{array}$} & EA 30 & -0.169 & 1.058 & $F=1.778$ \\
\hline & CA 24 & 0.167 & 0.980 & d.f. $=139$ \\
\hline & EI 30 & -0.130 & 1.049 & $P=0.137$ \\
\hline & $\mathrm{SA}_{30}$ & -0.175 & 0.973 & \\
\hline & TRC 26 & 0.392 & 0.851 & \\
\hline
\end{tabular}


architecture and a high positive mean score for tree biomass and tree height. SA had high positive mean score for forest architecture and tree biomass but also a low negative mean score for tree height. EI had a high negative mean score for tree biomass, while TRC had high positive mean scores for density of palm trees, vines and lianas, and density of canopy cover. In summary, the forest habitat at EA is classified as primary Seasonally Flooded Swamp forest, characterized by high tree biomass (large number of tall and very large trees), high tree turnover (frequent tree falls and regeneration) high density of palm trees, vines and lianas, broken canopy cover and open mid-canopy cover (many trees branching below half their height). At CA the forest habitat is partially disturbed Old Floodplain/ Seasonally Flooded Swamp forest characterized by fairly closed canopy, low tree biomass (short, fairly small trees), with some trees branching below half their height. The Terra Firme Sandy Clay forest at EI is classified as disturbed habitat (some trees branching below half their height and showing signs of regeneration), with low tree biomass (short, small trees, low tree density) and broken canopy cover. The habitats surveyed at both SA and TRC are primary floodplain forest habitats, showing few signs of disturbance (few trees branching below half their height or showing signs of disturbance), high tree biomass (many tall and very large trees), high density of palm trees and closed canopy cover.

Significant differences between each of the PCA variables at all five sites were tested for using one-way ANOVA (with Tukey post-hoc tests). EA differed significantly from $\mathrm{CA}$ in forest architecture (mean difference $=-0.79, \mathrm{SE}=0.30, P<0.05$ ) and tree height (mean difference $=0.87, \mathrm{SE}=0.26, P<0.05$ ). EA also differed significantly from SA both in forest architecture (mean difference $=-0.98$, $\mathrm{SE}=0.25, P<0.05)$ and in the number of palm trees, and trees with vines and lianas (mean difference $=-0.75, \mathrm{SE}=0.23, P<0.01$ ). There was a significant difference in the number of palm trees, and trees with vines and lianas, between TRC and all other four sites (between EA, mean difference $=-0.48, \mathrm{SE}=0.24, P<0.001$; between $\mathrm{CA}$, mean difference $=-0.91, \mathrm{SE}=0.25, P<0.01$; between $\mathrm{EI}$, mean difference $=-1.32, \mathrm{SE}=0.24, P<0.001$; between $\mathrm{SA}$, mean difference $=-0.64, \mathrm{SE}=0.24$, $P<0.05$ ). EI differed significantly from EA in tree biomass (mean difference $=0.92$, $\mathrm{SE}=0.24, P<0.01$ ) and tree height (mean difference $=0.74, \mathrm{SE}=0.24, P<0.05)$. SA differed significantly from EI in tree biomass (mean difference $=-0.92, \mathrm{SE}=0.24$, $P<$ O.01) and the number of palm trees and trees with vines and lianas (mean difference $=-0.68, \mathrm{SE}=0.23, P<0.05)$, while SA also differed significantly from $\mathrm{TRC}$ in tree biomass (mean difference $=0.73, \mathrm{SE}=0.25, P<0.05$ ).

\section{Bird census}

Three species, F. deiroleucus, H. stresemanni and S. schistacea, were not recorded during the VCP census. For the last species this may be due to its nomadic ecology that may be linked to seeding Guadua bamboo (Parker et al. 1996). $N$. dachilleae and E. tucinkae were not recorded during VCP surveys due to their preference for Lower Floodplain (river-edge) forest, which was not a focal habitat for this study. M. guianensis, $H$. harpyja and $P$. porhyrolaema $(n=1,3$ and 2 respectively) were also not recorded during VCP surveys but individuals were observed at EI, SA and TRC during hours of general observations. D. americanus was present in all five of the forest habitat types. Density estimates were also not 
possible for F. rufifrons, which was recorded during VCP census at TRC with too few records, but only during hours of general observations at both EA and CA.

Of the nine globally threatened species, P. leucoptera had the highest density estimate per square kilometre (in primary Seasonally Flooded Swamp forest) (Table 3). For all three large macaw species, density estimates were higher in primary forest habitats than in disturbed forests. Neither $A$. macao nor $P$. leucoptera was recorded in disturbed Terra Firme Sandy Clay forest. A. chloroptera was more abundant in primary Old Floodplain forest than in the other primary forest sites. Density estimates for the other macaw species were highest in the primary Middle/Upper Floodplain forest. Of the bamboo specialists, density estimates were highest at the SA site for C. spectabilis, C. manu and P. albifacies where the bamboo understorey was more extensive, while $S$. ucayalae was more abundant at TRC. Density estimates and the conservation of C. mcilhennyi have already been examined in detail elsewhere (Lloyd 200ob).

Kratter (1995b) estimated the amount of available floodplain forest habitat to be $9,468 \mathrm{~km}^{2}$, floodplain forest with bamboo understorey to be between $117 \mathrm{~km}^{2}$ and $1,076 \mathrm{~km}^{2}$, bluff-top bamboo habitat to be $249 \mathrm{~km}^{2}$ and terra firme forest to be $16,867 \mathrm{~km}^{2}$. Of this, Kratter (1995b) calculated from a satellite image of the region, that $30 \%$ of all floodplain forests were earmarked for protection within the PNBS. Based on these figures, I have calculated regional population estimates for the region in the satellite image (Table 4 ). In order to calculate the proportion of both the floodplain and terra firme forest populations now offered protection within the PNBS I have simply calculated 30\% of the regional population. For bamboo specialists, their floodplain forest populations are augmented by the presence of bluff-top bamboo habitats, $75 \%$ (approximately $186 \mathrm{~km}^{2}$ ) of which fall within the boundaries of PNBS (Kratter 1995b). Thus I have calculated

Table 3. Encounter rates and population densities (expressed as number of individuals or pairs per $\mathrm{km}^{2}$ ) of nine globally threatened species in each forest type.

\begin{tabular}{|c|c|c|c|c|c|}
\hline Species & $\begin{array}{l}\text { Primary } \\
\text { Seasonally } \\
\text { Flooded Swamp } \\
\text { forest }\end{array}$ & $\begin{array}{l}\text { Partially } \\
\text { disturbed Old } \\
\text { Floodplain/ } \\
\text { Seasonally } \\
\text { Fooded } \\
\text { Swamp forest }\end{array}$ & $\begin{array}{l}\text { Disturbed } \\
\text { Terra Firme } \\
\text { Sandy Clay } \\
\text { forest }\end{array}$ & $\begin{array}{l}\text { Primary Old } \\
\text { Floodplain } \\
\text { forest with } \\
\text { Guadua } \\
\text { bamboo }\end{array}$ & $\begin{array}{l}\text { Primary } \\
\text { Middle/Upper } \\
\text { Floodplain } \\
\text { forest with } \\
\text { Guadua } \\
\text { bamboo }\end{array}$ \\
\hline Psophia leucoptera & $3.0(10.8 \pm 5.0)$ & NR & NR & + & + \\
\hline Ara ararauna & $1.1( \pm 9.5)$ & $1.1( \pm 49.3)$ & + & + & $3.4( \pm 4.9)$ \\
\hline Ara chloroptera & $1.3( \pm 6.4)$ & + & $1.3( \pm 6.6)$ & $2.0( \pm 4.9)$ & $1.3( \pm 3.1)$ \\
\hline Ara macao & $0.5( \pm 7.5)$ & + & NR & + & $2.6( \pm 3.0)$ \\
\hline Celeus spectabilis & NR & NR & NR & 1.9 (pairs) & NR \\
\hline Simoxenops ucayalae & NR & NR & NR & $4.7( \pm 7.2)$ & $7 \cdot 7( \pm 2.1)$ \\
\hline Cecromacra manu & NR & NR & NR & 3.7 (pairs) & NR \\
\hline $\begin{array}{l}\text { Formicarius } \\
\text { rufifrons }\end{array}$ & $n=1$ & $n=2$ & NR & NR & + \\
\hline $\begin{array}{l}\text { Poecilotriccus } \\
\text { albifacies }\end{array}$ & NR & NR & NR & $4.4( \pm 2.3)$ & + \\
\hline
\end{tabular}

NR, not recorded during VCP or VDLT surveys; +, density too low to estimate; $n$, number of individuals recorded during hours of general observation. 
Table 4. Regional population estimates for globally threatened species found in the Tambopata province, south-east Peru. Population estimates are expressed as total number of individuals or pairs. Estimates are based on the area of forest cover from Kratter (1995b).

\begin{tabular}{|c|c|c|c|}
\hline Species & Habitats & $\begin{array}{l}\text { Regional population } \\
\text { estimate (number of } \\
\text { individuals or pairs) }\end{array}$ & $\begin{array}{l}\text { Population estimate for Parc } \\
\text { Nacional Bahuaja-Sonene and } \\
\text { Reservada Nacional de } \\
\text { Tambopata (no. of } \\
\text { individuals or pairs) }\end{array}$ \\
\hline Psophia leucoptera & $\begin{array}{l}\text { Floodplain }+ \\
\text { swamp forests }\end{array}$ & 102,254 & 30,672 \\
\hline Ara ararauna & $\begin{array}{l}\text { Floodplain }+ \\
\text { swamp forests }\end{array}$ & 9,941 to 31,718 & 2,982 to 9,514 \\
\hline Ara chloroptera & $\begin{array}{l}\text { (a) Floodplain }+ \\
\text { swamp forests } \\
\text { (b) Terra firme forests }\end{array}$ & $\begin{array}{l}\text { (a) } 12,024 \text { to } 18652 \\
\text { (b) } 21,758\end{array}$ & $\begin{array}{l}\text { (a) } 3,607 \text { to } 5,595 \\
\text { (b) } 9,906 \text { to } 15,366\end{array}$ \\
\hline Ara macao & $\begin{array}{l}\text { Floodplain }+ \\
\text { swamp forests }\end{array}$ & 4,734 to 24,332 & 1,420 to 7,299 \\
\hline Celeus spectabilis & $\begin{array}{l}\text { Floodplain forest with } \\
\text { bamboo understorey }\end{array}$ & 215 to 1,980 pairs & 422 to 969 pairs \\
\hline $\begin{array}{l}\text { Simoxenops } \\
\text { ucayalae }\end{array}$ & $\begin{array}{l}\text { Floodplain forest with } \\
\text { bamboo understorey }\end{array}$ & 550 to 8,285 & 1,043 to 3,925 \\
\hline Cecromacra manu & $\begin{array}{l}\text { Floodplain forest with } \\
\text { bamboo understorey }\end{array}$ & 431 to 3,961 pairs & 821 to 1,886 pairs \\
\hline $\begin{array}{l}\text { Formicarius } \\
\text { rufifrons }\end{array}$ & $\begin{array}{l}\text { Lower Floodplain } \\
\text { forest }\end{array}$ & 350 to 3,000 pairs $^{a}$ & 150 to 500 pairs $^{a}$ \\
\hline $\begin{array}{l}\text { Conioptilon } \\
\text { mcilhennyi }\end{array}$ & $\begin{array}{l}\text { Seasonally Flooded } \\
\text { Swamp + floodplain } \\
\text { forests }\end{array}$ & 1,153 to $2,178^{b}$ & $\begin{array}{l}\text { Population not found in } \\
\text { protected area }\end{array}$ \\
\hline $\begin{array}{l}\text { Poecilotriccus } \\
\text { albifacires }\end{array}$ & $\begin{array}{l}\text { Floodplain forest with } \\
\text { bamboo understorey }\end{array}$ & 515 to 4,734 & 976 to 2,243 \\
\hline
\end{tabular}

${ }^{a}$ From Kratter (1995a); ${ }^{b}$ from Lloyd (200ob).

population estimates for four threatened bamboo specialists in this habitat using the density estimates (Table 3 ) and have included these figures in the protected population estimates (Table 4 ).

\section{Discussion}

Reliable and quantitative information on the habitat and populations of forest bird communities in South America is still lacking (Terborgh et al. 1990). Only recently have biologists conducted population estimates for Neotropical bird species (e.g. in Peru: Terborgh et al. 1990, Kratter 1995b, Lloyd 200ob; Ecuador: Jacobs and Walker 1999; French Guiana: Thiollay 1994; and Brazil: Marsden et al. 2000). Fewer studies have also provided an in-depth analysis of habitat structure at the same sites as the bird census. Using such an approach, this study has shown that in Tambopata each of the five sites had different forests with significantly different habitat components; also that population densities of threatened lowland forest bird species differ between forest habitats, and that threatened bird species occur at different population densities between different primary forest habitats and between primary and disturbed forests. As a result of this quantitative approach, I am able to make a number of predictions regarding 
future habitat alterations and their effect on local population densities of some of the threatened bird species and also to make some broad statements regarding their conservation status.

\section{Diurnal raptors}

I was unable to calculate density estimates for the four species of raptor for two principal reasons. Firstly the size of each census area was too small. Secondly the fact that both species were only observed outside of surveys reflects the unsuitability of the method to survey large diurnal raptor species (and therefore the genuine rarity of both species). A combination of spot-mapping over a wider area and direct counts of nests and measuring mean distance between adjacent nests is probably a more reliable way to survey both these species. Two previous studies have revealed that $H$. harpyja requires large territory sizes, estimated at $45-79 \mathrm{~km}^{2}$ per pair in Panama and Venezuela (Alvarez-Cordero 1996). In French Guiana, Thiollay (1989) estimated a density of 3.1 individuals per $100 \mathrm{~km}^{2}$ of primary lowland forest. If these estimates are used in lowland forest habitat in the PNBS, one could extrapolate a maximum population size of 200 to 350 individuals within the park boundaries. Records of M. guianensis are less numerous in Tambopata. Overall its population size within PNBS is probably no greater than that of $H$. harpyja.

D. americanus was recorded during every census in the partially disturbed forest at CA, whilst it was recorded on $50 \%$ of visits to each of the other four sites. Robinson (1994) recorded the species on average every 3-10 census visits during a 41-month period at Cocha Cashu between 1979 and 1989. This species is not globally threatened or at risk locally in the Tambopata region since it is commonly recorded in both primary and disturbed forest habitats. D. americanus is rated as vulnerable by Parker et al. (1996), primarily on the basis of unexplained population "crashes" in portions of its range (in Central America and South America west of the Andes), but such declines have not been noted in south-western Amazonia.

\section{Pale-winged Trumpeter}

The density estimate of 3 breeding groups per $\mathrm{km}^{2}$ of primary Seasonally Flooded Swamp forest for P. leucoptera is higher than that obtained from two previous studies at the Estacion Biologica Cocha Cashu in Parque Nacional Manu. Terborgh et al. (1990) encountered densities of 9 individuals per $\mathrm{km}^{2}$ in mature floodplain forest while Sherman (1995) estimated densities of between 4 and 13 individuals per $\mathrm{km}^{2}$ within the same forest habitat. Using the estimate for the number of breeding groups (Table 3), this would imply a density estimate of 12-39 individuals per $\mathrm{km}^{2}$ of forest habitat based upon Sherman (1995), 27 individuals per $\mathrm{km}^{2}$ forest habitat based on Terborgh et al. (1990) and a total of 30 individuals per $\mathrm{km}^{2}$ forest habitat based on the data from this study. These densities are extremely high and the density estimate in Table 3 could be viewed as being an overestimate.

$P$. leucoptera is more abundant and more commonly encountered in primary forest habitats with tall trees and a high tree biomass (Tables 1, 3). Selective 
logging operations that would affect either of these factors would have an adverse effect on the local population density. It is apparent that P. leucoptera is threatened locally in Tambopata in disturbed forest habitats, particularly those which have been established for a number of years and that are in close proximity to areas of human habitation, such as the CA and EI reserves. Large terrestrial birds such as trumpeters, various cracids and tinamous are invariably the first birds to be hunted following nearby settlement (Robinson and Terborgh 1990). P. leucoptera is not, however, globally threatened based upon the density estimates in primary Seasonally Flooded Swamp forest in Table 3 and the population estimate within the PNBS (Table 4).

\section{Parrots}

The density estimates for the three macaw species are very similar to those calculated by Terborgh et al. (1990) at the Estacion Biologica Cocha Cashu in Parque Nacional Manu, who calculated density estimates of 1 pair per $\mathrm{km}^{2}$ in mature floodplain forest for all three species. Both these studies show that large macaw species occur at low population densities per square kilometre of habitat. Furthermore this study has shown that these macaw species occur at higher densities in primary forest habitats than in disturbed forests, particularly in primary forests with a high tree biomass and a high proportion of palm tree species. Any selective logging operation that reduces the overall tree biomass and removes a high proportion of palm trees from primary forest habitats will have an adverse effect on local macaw population density. Overall these three macaw species are not globally threatened since they all have a significant regional population estimate and protected population within the PNBS and RNT.

\section{Rufous-fronted Antthrush}

I was unable to provide any further quantitative data regarding the conservation of F. rufifrons. The lack of records during the census was principally due to its preference for Lower Floodplain forests, which was not a focal habitat for this study, rather than the unsuitability of the census method. A small area of this habitat was found in close proximity to some of the census stations at TRC that resulted in the species being recorded during the VCP census. One of the foremost priorities for conservation biology in the Tambopata region must now be an extensive survey of these Lower Floodplain forests, targeting both this species and also N. dachilleae.

F. rufifrons has recently been discovered in adjacent Bolivia and Brazil (BirdLife International 2000) and the species is apparently able to persist in human-altered landscapes adjacent to Parque Nacional Manu (Robinson and Terborgh 1997). However, the species has a restricted distribution within a linear habitat, $80 \%$ of which is under threat due to habitat loss caused directly by human settlement (Kratter 1995a, Krabbe and Schulenberg 2003). The remaining $20 \%$ of its population is found within the two principal protected areas in south-eastern Peru, namely Parque Nacional Manu and the PNBS (Kratter 1995a, 
Krabbe and Schulenberg 2003). Its range has become severely fragmented and the main cause for concern is now the connectivity of the various populations. Even within the PNBS the population of 150 to 500 pairs that inhabits the Lower Floodplain forests of the upper Rio Tambopata is now cut off from any other local antthrush population due to the near-total settlement of people along the lower Rio Tambopata (Kratter 1995a). F. rufifrons is probably capable of some distance movements provided there are suitable habitat corridors (Krabbe and Schulenberg 2003). I have seen a number of new territories become established and other known territories become "abandoned" in Lower Floodplain and Seasonally Flooded Swamp forest-edge habitats along the upper Rio Madre de Dios within the last 3 years, leading to the possibility that there is a sizeable population of F. rufifrons in this area. Further territories have also become established at EA since the completion of data collection (E. Barnes pers. comm.).

\section{Black-faced Cotinga}

Terborgh et al. (1990), Robinson and Terborgh (1997) and Lloyd (200ob) have shown that Conioptilon mcilhennyi occurs at low population densities and is largely restricted to Seasonally Flooded Swamp forests and other successional vegetation along floodplains. This would account for the species not being recorded at EI, SA and TRC. Logging operations and the conversion of these habitats to agriculture would have a major impact on cotinga populations in the region (Robinson and Terborgh 1997). Recent logging concessions such as those granted to communities along the Rio Colorado, threaten not only the population on the north bank of the Rio Madre de Dios, but the remainder of the population discussed by Lloyd (200ob). Currently the only known protected population of C. mcilhennyi lies within Manu Biosphere Reserve. When PNBS was extended to include the Tavara-Candamo region of the former ZRTC, the area of floodplain and Seasonally Flooded Swamp forest on the north bank of the Rio Madre de Dios, east of Puerto Maldonado to the Bolivian frontier was excluded despite recommendations for its inclusion (Lloyd 200ob). The conservation status of this species must be reviewed in the short-term future.

\section{Bamboo specialists}

The density estimates for all bamboo specialists are lower than those calculated at the TRC by Kratter (1995b). In some cases, Kratter's density estimates, calculated using standardized spot-mapping methodology, are remarkably high for small tropical birds, e.g. 25 pairs per $\mathrm{km}$ for C. manu. Of course the density estimates obtained in both these studies are just as likely to be "correct", but what is most apparent from both these studies is that bamboo habitats do not lend themselves readily to most census methods and follow-up studies of densities of bamboo specialists and detailed measurements of the bamboo habitat are urgently required.

All bamboo specialists have a large proportion of their populations located within the current boundaries of the PNBS and RNT (with three species having a population estimate within the region of 1,000 individuals). S. ucayalae is still 
considered globally threatened by BirdLife International (2000). Whilst apparently tolerant of small-scale timber extraction (BirdLife International 2000) its high degree of habitat specificity (classified as a near-obligate bamboo specialist by Kratter 1995b) places it at risk where the bamboo habitat is threatened by wholesale clearance for agriculture (Kratter 1995b, BirdLife International 2000). C. spectabilis is also considered as a near-obligate bamboo specialist by Kratter (1995b, 1997). From what is now known of its habitat and nesting requirements and its low population densities, the species is probably globally threatened and warrants Near Threatened status (Lloyd 2000a, Winkler and Christie 2002).

P. albifacies and C. manu are obligate bamboo specialists. C. manu occurs at higher population densities per square kilometre of floodplain forest bamboo than $P$. albifacies and can be found in secondary colonizing bamboo habitats along roadsides (Kratter 1995b). In Brazil, isolated populations of C. manu may be threatened by the rampant decrease in bamboo habitats due to clearance for agriculture (Zimmer and Isler 2003). P. albifacies is currently only known from undisturbed bamboo habitats. Not only are its breeding requirements unknown but it is also not known whether the species is tolerant of small-scale timber extraction from floodplain forests where Guadua bamboo habitat is the dominant understorey vegetation. Both these obligate bamboo specialists occur at low population densities (Table 3 ) in habitat that is rare and patchily distributed and they should be monitored for any population declines.

\section{Protected lowland areas in south-east Peru}

Large contiguous areas of primary forest habitats are needed to protect populations of globally threatened lowland forest bird species. This is particularly necessary for large arboreal granivores that wander seasonally (Robinson and Terborgh 1990), large forest-dwelling raptors that have large territory sizes (Robinson 1994), large terrestrial species that are at risk from localized hunting (Robinson and Terborgh 1990) and habitat-restricted endemics that exist at low population densities in rare and patchy habitats. Robinson and Terborgh (1990) state that the 1,600,000 ha Parque Nacional Manu may be just large enough to maintain adequate populations of these species. The importance of this study is that we now have regional population estimates for different forest habitats, for one of the largest national parks in Peru that can serve as an indicator for what is required to protect significant populations of lowland forest bird species. Even in PNBS the population of bamboo specialists is not very large. In fact only $P$. leucoptera and $A$. chloroptera can be said to have substantial numbers (i.e. greater than 10,000 individuals) within the park boundaries. However, the population estimates for some of these threatened species are likely to be higher, particularly for P. leucoptera and the three macaw species, since they also occur in undisturbed terra firme and foothill forest habitats in the Upper Rio Tambopata and Rio Tavara (pers. obs).

Populations of these threatened bird species will probably be found within the boundaries of the newly created 5,000,00o ha Alto Purus Reserved Zone. Created in October 2000, the majority of this reserve zone lies within the department of Ucayalae, but within the department of Madre de Dios it incorporates the region of the "Purus Triangle" (which already contains a number of small settlements) 
and links up with the northern boundary of Parque Nacional Manu. It is also possible that populations of these species occur within the boundaries of two other protected areas: the Amara Kaeri Reserve Zone, south-east of Parque Nacional Manu, and the Los Amigos Conservation Concession, which protects approximately 137,591 ha of "old growth" lowland forest in the lower Rio de Los Amigos watershed. Both these areas not only protect the eastern flank of Parque Nacional Manu but also part of the lowland forest corridor that links it to Parque Nacional Bahuaja-Sonene.

\section{Acknowledgements}

I would like to thank Arturo Palomino, Juan Carlos Oyola, Chris Kirkby, Alexi Nunez and John Hazelmyer for helping to establish the research sites and co-ordinate data collection. Many thanks go to the volunteers of Proyecto Tambopata who made the project possible by helping to collect the data and who contributed financially to the research. B. Walker, E. Barnes, C. Kirkby and U. Valdez provided additional information. S. Marsden greatly assisted with habitat data analysis. Permission to undertake fieldwork in the TCRZ was granted by the Director of the National Institute of Natural Resources (INRENA). Financial support was provided by: the Grand Circle Foundation, Lindeth Charitable Trust, Albert Reckitt Trust, Andrew Lloyd, the Anglo-Peruvian Society and the Tambopata Reserve Society. The Royal Geographical Society (UK) and Conservation International (Peru) provided institutional approval for the initial research proposal. Facilities and logistical support to the study areas were kindly provided by: J. Koechlin and P. Purisaca (Cuzco Amazonico Reserve); M. Gunther (Explorers Inn); J. Toledo (EcoAmazonia Lodge); Newton College-Lima and P. van Ipenberg, (Sachavacayoc Centre); E. Nycander, K. Holle, M. Napravnich and P. Rojas (Tambopata Research Centre). A. Kratter and an anonymous reviewer provided comments on the manuscript.

\section{References}

Alvarez-Cordero, E. (1996) Biology and conservation of the Harpy Eagle in Venezuela and Panama. Ph.D. Dissertation. University of Florida, Gainesville.

Bibby, C. J., Jones, M. J. and Marsden, S. J. (1998) Expedition field techniques: bird surveys. London: Expedition Advisory Centre, Royal Geographic Society/BirdLife International.

Bibby, C. J., Burgess, N. D., Hill, D. A. and Mustoe, S. H. (2000) Bird census techniques. Second edition. London: Academic Press.

BirdLife International (2000) Threatened birds of the world. Barcelona and Cambridge, U.K.: Lynx Edicions and BirdLife International.

Buckland, S. T., Anderson, D. R., Burnham, K. P. and Laake, J. T. (1993) Distance sampling: estimating abundance of biological populations. London: Chapman and Hall.

Collar, N. J., Crosby, M. J. and Stattersfield, A. J. (1994) Birds to watch 2: the world list of threatened birds. Cambridge, U.K.: BirdLife International (BirdLife Conservation Series no. 4).

Earth Observation Satellite Company (1991) Landsat thematic mapper scene 432981356410809. Path 002, row 069. Colour bands 3, 4, 5. Image date: 27 July 1991. Lanham, Maryland, USA. 
Foster, R. B., Parker III, T. A., Gentry, A. H., Emmons, L. H., Chicchon, A., Schulenberg, T., Rodriguez, L., Lamas, G., Ortega, H., Icochea, J., Wust, W., Rono, M., Castillo, J. A., Phillips, O. L., Reynel, C., Kratter, A., Donahue, P. K. and Barkley, L. J. (1994) The Tambopata-Candamo Reserve Zone of south-eastern Peru: a biological assessment. Washington, D.C.: Conservation International (RAP working papers 6).

Jacobs, M. D. and Walker, J. S. (1999) Density estimates of birds inhabiting fragments of cloud forest in southern Ecuador. Bird Conserv. Internatn. 9: 73-79.

Jones, M. J., Lindsey, M. D. and Marsden, S. J. (1995) Population sizes, status and habitat associations of the restricted-range bird species of Sumba, Indonesia. Bird Conserv. Internatn. 5: 21-52.

Krabbe, N. K. and Schulenberg, T. S. (2003). Family Formicarridae (Ground Antbirds). Pp. 448-681 in J. E. del Hoyo and J. Sargatal, eds. Handbook of the birds of the world: Volume 8. Barcelona: Lynx Edicions.

Kratter, A. W. (1995a) Status, habitat and conservation of the Rufous-fronted Antthrush, Formicarius rufifrons. Bird Conserv. Internatn. 5: 391-404.

Kratter, A. W. (1995b) Bamboo specialisation in Amazonian birds. Ph.D. Dissertation. Louisiana State University, Baton Rouge, Louisiana.

Kratter, A. W. (1997) Bamboo specialisation in Amazonian birds. Biotropica 29(1): 100-110.

Lloyd, H. (2000a) Nesting behaviour of the Rufous-headed Woodpecker Celeus spectabilis. Bull. Brit. Orn. Club. 120(2): 129-132.

Lloyd, H. (200ob) Population densities of the Black-faced Cotinga Conioptilon mcilhennyi in south-east Peru. Bird Conserv. Internatn. 10: 277-285.

Marsden, S. J., Whiffin, M., Sadgrove, L. and Guimarães Jr, P. (2000) Parrot populations and habitat use in and around two lowland Atlantic forest reserves, Brazil. Biol. Conserv. 96(2): 209-217.

Nicholson, B. and Edwards, J. (1994) Forest Classification Project: section A - vegetation analysis and ground truthing. In Report of the TReeS Tambopata-Candamo Expedition: a biological survey in the Tambopata-Candamo Reserve Zone, south-east Peru. London: Tambopata Reserve Society.

Norusis, M. J. (1993) SPSS for Windows Professional Statistics 6.1. Chicago: SPSS Inc.

Parker, T. A. III., Stotz, D. F. and Fitzpatrick, J. W. (1996) Ecological and distributional databases for Neotropical birds. In D. F. Stotz, J. W. Fitzpatrick, T. A. Parker III and D. K. Moskovits. Neotropical birds: ecology and conservation. Chicago: University of Chicago Press.

Phillips, O. L. (1993) Comparative valuation of tropical forests in Amazonian Peru. Ph.D. Dissertation. Washington University, St Louis, Missouri.

Phillips, O. L., Gentry, A. H., Reynel, C., Wilkin, P. and Glavez-Durand B, C. (1994) Quantitative ethnobotany and Amazonian conservation. Conserv. Biol. 8: 225-248.

Reynolds, R. T., Scott, J. M. and Nussbaum, R. A. (1980) A variable circular plot method for estimating bird numbers. Condor 82: 309-313.

Ridgely R. and Tudor, G. (1994) The birds of South America. Volume II. The suboscine passerines. Austin, Texas: University of Texas Press.

Robinson, S. K. (1994) Habitat selection and foraging ecology of raptors in Amazonian Peru. Biotropica 26(4): 443-458.

Robinson, S. K. and Terborgh, J. (1990) Bird communities of the Cocha Cashu Biological station in Amazonian Peru. Pp. 199-216 in A. H. Gentry, ed. Four neotropical rainforests. New Haven, Connecticut: Yale University Press.

Robinson, S. K. and Terborgh, J. (1997) Bird community dynamics along primary successional gradients of an Amazonian white-water river. Orn. Monogr. 48: 641-672.

Sherman, P. T. (1995). Breeding biology of white-winged trumpeters (Psophia leucoptera) in Peru. The Auk 112: 296-309.

Stotz, D. F., Fitzpatrick, J. W., Parker, T. A. III and Moskovits, D. K. (1996) Neotropical birds: ecology and conservation. Chicago: University of Chicago Press. 
Terborgh, J. W., Robinson, S. K., Parker, T. A. III., Munn, C. A. and Pierpont, N. (1990) The structure and organisation of an Amazonian forest bird community. Ecol. Monogr. 6o: $213-238$.

Thiollay, J. M. (1989) Censusing of diurnal raptors in a primary rainforest: comparative methods and species detectability. J. Raptor Res. 23(3): 72-84.

Thiollay, J. M. (1994) Structure, density and rarity in an Amazonian rainforest bird community. J. Trop. Ecol. 10: 449-481.

Thomas, L., Laake, J. L., Derry, J. F., Buckland, S. T., Borchers, D. L., Marques, F., Pollard, J. H. and Fewster, R. M. (1998) Distance 3.5. University of St Andrews, U.K.: Research Unit for Wildlife Population Assessment.

Torquebiau, E. F. (1986) Mosaic patterns in Dipterocarp rain forest in Indonesia and their implications for practical forestry. J. Trop. Ecol. 2: 301-325.

Winkler, H. and Christie, D. A. (2002). Family Picidae (Woodpeckers). Pp. 296-555 in J. E. del Hoyo and J. Sargatal, eds. Handbook of the birds of the world: Volume 7. Barcelona: Lynx Edicions.

Zimmer, K. J. and Isler, M. L. (2003). Family Thamnophilidae (Typical Antbirds). Pp. 682-731 in J. E. del Hoyo and J. Sargatal, eds. Handbook of the birds of the world: Volume 8. Barcelona: Lynx Edicions.

\section{HUW LLOYD}

TReeS-RAMOS, Casilla 28, Puerto Maldonado, Madre de Dios, Peru. Current address: Room E418, Department of Environmental and Geographical Sciences, Manchester Metropolitan University, John Dalton Extension Building, Chester Street, Manchester MI 5GD, U.K. (e-mail: H.Lloyd@mmu.ac.uk)

Received 17 December 2002; revision accepted 2 April 2004 